NBER WORKING PAPER SERIES

\title{
MONETARY TRANSMISSION IN THE EURO AREA: DOES THE INTEREST RATE CHANNEL EXPLAIN ALL?
}

\author{
Ignazio Angeloni \\ Anil K. Kashyap \\ Benoît Mojon \\ Daniele Terlizzese \\ Working Paper 9984 \\ http://www.nber.org/papers/w9984
}

\author{
NATIONAL BUREAU OF ECONOMIC RESEARCH \\ 1050 Massachusetts Avenue \\ Cambridge, MA 02138 \\ September 2003
}

\begin{abstract}
An earlier version of this paper was circulated as ECB Working Paper 114, titled "Monetary Transmission in the Euro Area: Where Do We Stand?". Kashyap thanks the ECB, the Houblon Norman Fund and the National Science Foundation (through a grant administered by the National Bureau of Economic Research) for financial support. The views expressed in this paper are not necessarily shared by the institutions to which the authors are affiliated. We are grateful to all members of the Eurosystem Monetary Transmission Network for their continuous co-operation and to the participants in the conference "Monetary Policy Transmission in the Euro Area", held at the ECB on 18 and 19 December 2001, for many helpful comments. We particularly thank A. Dieppe, M. Ehrmann and L. Monteforte for helping us assemble some of the data and S. Sommaggio for editing the text. All errors and shortcomings are our responsibility alone. The views expressed herein are those of the authors and are not necessarily those of the National Bureau of Economic Research.
\end{abstract}

C2003 by Ignazio Angeloni, Anil K. Kashyap, Benoît Mojon, and Daniele Terlizzese. All rights reserved. Short sections of text, not to exceed two paragraphs, may be quoted without explicit permission provided that full credit, including (C) notice, is given to the source. 
Monetary Transmission in the Euro Area: Does the Interest Rate Channel Explain All? Ignazio Angeloni, Anil K. Kashyap, Benoît Mojon, and Daniele Terlizzese

NBER Working Paper No. 9984

September 2003

JEL No. E52, E20

\section{$\underline{\text { ABSTRACT }}$}

Drawing on recent Eurosystem research that uses a range of econometric techniques and a number of new data sets, we propose a comprehensive description of how monetary policy affects the euro area economy. We focus mainly on three questions: (1) what are the stylized facts concerning the transmission of monetary policy for the area as a whole and for individual countries? (2) can the "classic" interest rate channel (IRC) alone, without capital market imperfections, explain these facts? (3) if not, is the bank lending channel a likely candidate to complete the story? We find plausible euro-area wide monetary policy responses for prices and output that are similar to those generally reported for the U.S. However, investment (relative to consumption) seems to play a larger role in euro area monetary policy transmission than in the U.S. We cannot reject the hypothesis that the IRC completely characterizes transmission in a few countries, and estimate it to be substantial in almost all. Where the IRC is not dominant, there is normally some direct evidence supporting the presence of a bank lending channel (or other financial transmission channel). The cases where financial effects appear important can be further split according to whether they primarily relate to consumption or investment.

Ignazio Angeloni

European Central Bank,

Kaiserstrasse 29, D-60311

Frankfurt am Main

Germany

ignazio.angeloni@ecb.int

Anil Kashyap

University of Chicago

Graduate School of Business

1101 E. 58th Street

Chicago, IL 60637

and NBER

anil.kashyap@gsb.uchicago.edu
Benoît Mojon

European Central Bank

Kaisersrasse 29, D-60 311

Frankfurt am Main

Germany

benoit.mojon@ecb.int

Daniele Terlizzese

Banca d'Italia

Servizio Studi

Via Nazionale 91, 00184

Roma

daniele.terlizzese@bancaditalia.it 


\section{Introduction}

In late 1999, the European Central Bank (ECB) launched, together with the National Central Banks (NCBs) of the countries that had just adopted the euro, a major research initiative to study the transmission of monetary policy. The objective was to put together, in a reasonably short time, a comprehensive set of information on how the monetary policy of the newly created central bank would affect the economy of the so-called "euro area". In this paper we provide a selective summary of the main findings contained in the 23 papers that were produced during this project - the full results, including a more complete version of this paper, are forthcoming in Angeloni, Kashyap, and Mojon (2003).

In doing so, we draw on three types of analyses that were conducted during the project. The first consists of (six) macroeconomic studies of both the entire euro area economy and the constituent countries. The second of (seven) studies of firm-level investment behavior. The third of (ten) studies that analyze bank-level balance sheets and income statements. The goal of this paper is to bring together disparate pieces of evidence to produce a unified picture. We put the emphasis on cross-checking these various pieces of evidence, with the belief that when many indicators point in a similar direction this is unlikely to be due to chance, while a finding that different indicators yield different conclusions suggests more cautious conclusions should be drawn. The stress on the need for cross-checking was indeed a central theme of the whole project. The reader interested in more details regarding the results should consult Angeloni, Kashyap, and Mojon (2003).

One important caveat to this exercise is that almost all of the empirical work relies on pre1999 data, before the introduction of the euro and the structural break associated with the creation of the ECB. As a result, the Lucas critique no doubt applies forcefully. Still, we believe that the evidence collected is relevant for several reasons.

First, the European Economic and Monetary Union (EMU) was a gradual process. It included a prior convergence in policies and economic performance during which agents had time to prepare and adjust. Much of this adjustment is likely to have occurred before 1999, some to be ongoing after the new currency is introduced. Data prior to 1999 are likely to contain early information about the new regime. Second, the use of panel data on firms and banks is intended

\footnotetext{
${ }^{1}$ The euro area is composed of all the countries that have adopted the euro as their currency. Currently, the area includes 12 of the 15 countries belonging to the European Union (the exceptions being Denmark, Sweden and the United Kingdom). The Eurosystem includes the ECB and the euro area National Central Banks.
} 
inter alia to reduce the need for a long time-series dimension. Moreover, panel data might help identifying structural parameters that can be viewed as approximately constant during the transition. Finally, the aforementioned emphasis on cross-checking different sources of evidence using alternative methodologies and data should be of help in uncovering unreliable results.

To organize the discussion in an interesting fashion (as opposed to offering a laundry list of results), we ask whether the evidence is consistent with the view that monetary policy transmission in the euro area can broadly be described as taking place through the classical interest rate channel (IRC). By IRC we mean the response of aggregate demand components, GDP and prices to the change in the policy controlled interest rate that would take place if there were no capital (and insurance) market imperfections ${ }^{2}$. Equivalently, the question we ask is whether such imperfections are crucial to understand the main features of monetary transmission in the euro area.

We focus on this specific "null hypothesis" for several reasons. First, since the IRC is the conventional way in which monetary policy is presumed to operate in a large, fairly closed economy with a developed financial system, it is logical to ask whether it can explain the facts before looking at alternatives. Second, the commonly accepted - if not always fully accurate picture of the euro area financial market is one in which banks play a dominant role. To check whether this prominence has implications for the transmission mechanism it is methodologically sound to start with a working assumption that denies any such assumption. Third, much of the concern that has been voiced about the potentially asymmetric effects of the single monetary policy appears to be grounded in observed asymmetries in the financial structure of firms or banks, as well as in their vulnerability to informational problems. These features would be clearly of little relevance if the IRC were to account for the bulk of the transmission mechanism. Finally, taking IRC dominance as the null hypothesis provides a disciplined way to look for alternative explanations. Highlighting the places where the interest rate effects do not appear to be the whole story helps identify where other channels (such as balance sheet, liquidity constraints, bank credit supply, and the like) may be important. This in turn can help guide the measurement and monitoring of the most relevant information for policymakers.

\footnotetext{
${ }^{2}$ The IRC would be the only channel through which monetary policy would affect aggregate spending in a closed economy where: (1) the central bank was able to influence the term structure of market real interest rates; (2) all agents were able to borrow and lend at those rates and, (3) all insurance possibilities with respect to credit risks were available. In this world, no agent's expenditure would be affected by the availability of liquidity or collateral, nor would precautionary motives to hold wealth arise.
} 
In reaching our assessment about the channels of transmission, we place relatively little weight on the exchange rate channel. One reason for doing so is that we expect domestic channels of monetary policy transmission to become more important for the euro area economy (which is relatively closed to international trade) than was previously true for the member countries. In addition, estimates of the exchange rate channel for the period prior to the euro should be more affected by the regime shift than estimates of domestic channels. Finally, the empirical evidence on the effects of monetary policy on exchange rates is very mixed: the response of exchange rates to monetary policy is notoriously hard to predict. For all these reasons, we will mainly focus on domestic channels in our analysis.

The remainder of the paper is organised into six parts. In section 2 we briefly explain the logic underlying our analysis, focusing in particular on how we intend to bring the various pieces of empirical evidence to bear on the issue.

Section 3 summarizes, as a background, the overall response to a monetary policy shift of both prices and quantities in the euro area. This section draws upon evidence from both Vector Autoregressive (VAR) models and large scale euro area models and includes some comparisons between the euro area and both euro area countries the U.S.

We then check in section 4 whether the interest sensitive components of GDP - those components of aggregate demand that are traditionally taken to be most subject to inter-temporal substitution effects (fixed investment and, in principle, durable consumption) - appear to be able to account for the bulk of the GDP response.

Section 5 introduces the microeconomic evidence on non-financial firms' behavior. These data are used to determine whether a prominent role in the transmission of interest sensitive components is also matched by a prominent role of the interest rate (or of the cost of capital) in driving the movements of those components.

Section 6 looks for evidence on banks' lending that would be consistent with non-interest channels of monetary transmission, to complement the assessment so far reached concerning the prominence of the IRC.

Section 7 contains our summary of the analysis. We first summarize our understanding of how policy effects appear to be transmitted in each euro area country, before reviewing the main findings for the overall euro area. 


\section{Combining disparate pieces of evidence}

Ideally, one would like to test for the dominance of the IRC in a sharp statistical sense, using a single encompassing model with the appropriate data. Unfortunately, a spate of structural changes (most recently, the introduction of the euro) and well-known data limitations preclude this for the euro area. Hence we need to draw upon rather disparate pieces of evidence, trying to make them comparable in order to discover similarities and to corroborate findings, but eventually we will need to use our judgement in deciding what they tell us. Our "testing strategy" thus yields a suggested interpretation of the empirical results; alternative interpretations may be possible, and we will flag them when appropriate.

The intuition for our approach is relatively simple. We will try to build up the case in favor of our "null hypothesis" that the IRC is the dominant channel of monetary transmission by checking whether we find evidence of conditions that should be true, or at least probable, if our null were true; the more of these conditions we are able to verify, and the more robust is the evidence in their favor - being confirmed by different approaches and data sets - the more confident we will be about our "null". 3

In particular, we will start checking whether interest sensitive spending categories (which we will take to be represented by investment ${ }^{4}$ account for the bulk of the spending changes that occur after a shift in monetary policy. This is a natural question to ask when assessing the role of the IRC. Plainly, if the IRC is important we should see important movements of those components of the expenditure that are traditionally taken to be more interest sensitive. However, it is also a question whose discriminatory power is rather weak. First, interest sensitive spending might move responding to channels different from the IRC. Second, even non-durable consumption might move in reaction to changes of the interest sensitive components. Finally, the dichotomy between interest sensitive and non-interest sensitive is not as sharp as economic textbooks would suggest. For all these reasons we see the analysis of the composition of the output response to a monetary policy shift as a suggestive step in analysing the role that is played by the IRC.

\footnotetext{
${ }^{3}$ This corresponds to one of the main "patterns of plausible inference" expounded by Polya (1954): “..if a certain circumstance is more credible with a certain conjecture than without it, the proof of that circumstance can only enhance the credibility of that conjecture". This is essentially an application of Bayes' theorem.

${ }^{4}$ Theory suggests that interest rates should influence other spending categories besides investment, notably durable consumption and inventory investment. Unfortunately, the lack of homogeneous data for many euro area countries prevents a fully satisfactory statistical measurement of these categories. Durable consumption is measured separately only in Italy, France and Finland. Likewise, in all countries but France and the Netherlands inventory investment is computed as a residual in the national income and product accounts. Thus, there is little one can do to systematically study how interest rate changes influence these variables. See Angeloni et al. (2003) for details.
} 
We will then move to ask a few more specific questions, using micro data on firms and banks. The first of these tries to address one of the difficulties in interpreting the composition of the output response mentioned above. We will ask whether there is evidence that the spending shifts appear to be due directly to changes in interest rates, not just indirectly because other determinants of such spending categories are affected by policy. We check whether the investment demand of firms adjust through the effect of policy on the user cost of capital or by changing the tightness of firms' liquidity constraints. We will also ask, in connection with the possible role of financial factors, whether any subsets of firms where one might think liquidity problems should be more acute show stronger sensitivities of investment to liquidity. A further kind of question moves from the idea that if financial frictions are important, it can be expected that banks play a role in amplifying and transmitting their effect throughout the economy. We will therefore also ask whether there is evidence of a strong role of bank loan supply shifts in amplifying the effects of interest rates.

The evidence we compile - first, by asking whether the response of interest sensitive components of spending account for the bulk of observed changes in aggregate demand; second, by checking whether such response can be explained, to a sufficiently large extent, by the direct effect of interest rate changes on investment; third, by checking for the presence of cash-flow or liquidity effects on investment and for independent evidence regarding banks' behavior following changes in monetary policy — allows us to pass a judgment about the nature of the transmission mechanism in the various countries.

\section{The overall effects of monetary policy in the euro area}

As a first step we present, in this section, some results concerning the effects of monetary policy on GDP and prices in the euro area. We gather four types of measures of these effects, using either country or euro area aggregate models ${ }^{5}$ and two econometric approaches: VARs and large scale models. All estimates are assembled from different chapters of Angeloni, Kashyap, and Mojon (2003), and these primary sources should be consulted for more detail.

\footnotetext{
${ }^{5}$ The euro area aggregate data that extend back to 1970 are an artificial construct and in principle pose several problems to the estimation of models for the area. It is however somewhat reassuring that euro area macroeconomic time series have been found to exhibit business cycle properties quite similar to the one observed in the U.S. (see Agresti and Mojon, 2003).
} 


\subsection{VAR estimates of the effects of monetary policy}

To start with, a set of basic VAR models for the euro area are estimated by Peersman and Smets (2003). In their models, an average short-term interest rate for the euro area is used as a proxy of the area-wide stance of monetary policy over the period. The main results can be seen in Figure 1, which displays a comparison of the impulse responses from two different models of the euro area (one without and one with M3 as an endogenous variable) and one model for the U.S. (that uses an identification scheme quite similar to the one of Christiano, Eichenbaum and Evans, 1999).

In both economies, the interest rate increase reduces output for a few quarters; the recovery starts within roughly one and a half years. Both in the U.S. and in the euro area, the price level gradually falls after a monetary tightening. The decline is not significant in either region for several quarters, but eventually the effect becomes strongly significant and permanent. The magnitudes of the responses are comparable if one corrects for the differences in the size of the initial interest rate shock. The similarity between the impulse responses in the euro area and the U.S. increases if one focuses on the euro area model with M3. The latter model may be more appropriate for the euro area over our sample period, in light of the prominence assigned to monetary aggregates by a number of central banks.

The effects of monetary policy on the GDP and prices of the euro area aggregate are also broadly consistent with the effects of monetary policy shocks identified within each country. Figure 2 shows results obtained using VAR models as in Mojon and Peersman (2003).

We must stress that, given the monetary policy regime differences between the countries during the period over which these VARs were estimated, comparisons of the quantitative results across countries are not warranted. But qualitative comparisons are still valid and several results follow from a direct comparison of the findings at the country level and for the euro aggregate VARs. First, a monetary tightening leads to a reduction in output and inflation in virtually all countries and in the euro area as a whole. While this is not surprising, since this prediction was undoubtedly one of the things that the model builders considered in settling on their preferred specifications, it is nevertheless reassuring to observe that this presumption is confirmed by the data. A second observation, probably more informative, is that the peak response of inflation comes after the peak response in output for essentially all the estimates.

A third observation is that a close examination of the country level VARs reveals a few counter-intuitive results. The VAR point estimates for Austria, Greece, Ireland and the 
Netherlands imply that a monetary tightening is expected to raise either output (see Table 3) or investment (see Mojon and Peersman, 2003) or both at some point in the first three years. However, once uncertainty is accounted for, often the estimates are not significantly different from zero. We therefore put more weight on structural models for these countries in forming our judgments.

\subsection{Evidence from large-scale econometric models}

Alternative estimates of the impact of changes in the short-term interest rate can be calculated using large-scale econometric models that are maintained by central banks for use in policy analysis. The criticisms of these models are well-known, but we view them as providing a useful an independent robustness check on the VARs.

We rely on a host of these models. The first is the Area-Wide Model (AWM) of Fagan, Henry and Mestre (2001). This model treats the entire euro-area as an integrated economy and is used for policy analysis at the ECB. A second set of models are the individual country-level models that have been developed over the years by each the euro area national central banks (NCBs). Harmonized simulations (imposing common interest rate and exchange rate assumptions) by van Els et al (2003b) have been used to construct a "bottom up" aggregated set of results for the euro area. As a comparison we also report simulations from the FRB/US model, the large scale model used by the staff of the Board of Governors of the Federal Reserve System. ${ }^{6}$

These results are presented in Table 1 for the euro area aggregates and the U.S., and in upper panel of Table 3 for country level evidence. The tables show the percentage deviations from the baseline following an exogenous change in the short-term rate (by 100 basis points for eight quarters, returning to baseline afterwards) and associated paths for the exchange rate and the longterm interest rate, consistent with arbitrage relationships (see van Els et al. (2003b) for a discussion).

The qualitative pattern of the response of output and prices already seen in Figure 1 is broadly confirmed by the structural model simulations, despite the differences in the models and the profiles of the shocks. Specifically, on both sides of the Atlantic, one observes a relatively quick and strong output response whereas the price response is muted. ${ }^{7}$

\footnotetext{
${ }^{6}$ We are grateful to the Flint Brayton for providing us with these simulations.

${ }^{7}$ See also van Els et al. (2003a) for a more thorough comparison of monetary policy shocks simulations with structural models and VARs.
} 


\subsection{The exchange rate channel}

Before further describing the domestic channels of transmission, we briefly compare the effects of an exchange rate shock in the euro area and the U.S. In van Els et al. (2003b), the decomposition of the effects of monetary policy shocks showed that, up to one year, the exchange rate channel of monetary policy is the dominant mover of euro area GDP and prices. Table 2 shows the percentage changes relative to the baseline following a permanent exogenous change in the nominal effective exchange rate (by 5 percent). For comparison's sake similar results for U.S. are also presented.

This "pure" exchange rate shock shows that, again most markedly in the short run, the euro area GDP and prices are more sensitive to changes in the exchange rate than their U.S. counterparts. While these responses to the exchange rate obviously need to be factored in the evaluation of the monetary policy stance, it is not obvious how to do this appropriately nor that, in practice, the exchange rate channel is large in the transmission of monetary policy. The path of the exchange rate in the van Els et al. (2003b) simulation and Table 1 imposes an uncovered interest rate parity condition. However, the strong link between interest rates and exchange rates that is so assumed, and that are central to establish the importance of the exchange rate channel in the transmission mechanism, cannot be taken for granted. In fact, there is considerable evidence showing that the uncovered interest parity assumption is empirically falsified. Moreover, with the change in the monetary policy regime that accompanied the introduction of the euro the link between short-term interest rates and exchange rates is particularly uncertain.

\subsection{Overall summary of the euro aggregate evidence}

We read the evidence in this section as suggesting two broad conclusions. First, VAR and large scale model analyses for the euro area confirm plausible monetary policy effects on output and prices. In the VARs, an unexpected increase in the short-term interest rate temporarily reduces output, with the peak effects occurring after roughly one year. Prices respond more slowly, hardly moving during the first year and then falling gradually over the next few years. Again, these VAR properties are similar to those reported for the U.S. The structural models of the U.S. and the euro area broadly confirm this picture.

Second, there is one interesting difference between the euro area and the U.S.. Changes in the exchange rates have, in the short-run, larger effects on GDP and prices in the euro area. As we 
will see in the next section, there is a further interesting difference between the effects of monetary policy in the U.S. and the euro area: the difference in the composition of the GDP response to a monetary policy shock. We find the composition of the output response interesting, as it is suggestive of the relative importance of interest sensitive spending shifts.

\section{The composition of the output response following a monetary shock}

To study the composition of the output response we study the ratios between the derivatives with respect to the interest rate of investment and consumption, on the one hand, and GDP on the other. To put it in plain English, we measure the total change in investment (or consumption) following a shift in monetary policy relative to the total change in GDP. We refer to this measure as the contribution of investment (or consumption) to the overall GDP change ${ }^{8}$. The idea is that these contributions can more easily be compared across models and countries, thus alleviating the problems of comparability among VARs and structural models. This is because, since we are comparing how much one variable moves relative to another following a policy shift, the nature of the shock moving both should be less relevant ${ }^{9}$.

While providing a convenient summary of the composition of the output response, the investment (or consumption) contribution suffer from a few shortcomings. One problem (alluded to earlier) is that we cannot independently measure all the components of spending that we expect to be interest sensitive. At this point, all that we can consistently study is private consumption and total investment. This means that we cannot parse out the effects of changes in durable consumption expenditure from the rest of consumption. Similarly, the investment responses that we measure include the movements in government investment, but exclude shifts in inventories.

A second problem is what to do about exchange rate channel effects. As mentioned earlier, we expect this channel in the future to be less powerful than before the creation of the currency area. But we cannot deny the fact that this channel could have been important in some episodes of the last two decades. To abstract from the role of the exchange rate channel we

\footnotetext{
${ }^{8}$ In the case of VAR simulations, where the interest rate shocks only last one period, the contribution is based on the cumulated responses of GDP and investment (or consumption). This smoothes out some of the short-run noise. Also, note that cumulating up to time $t$ the responses to a one-off shock occurring in $t$ - $k$ is approximately equivalent to observe, at time $t$, the response to a shock sustained from $t$ - $k$ to $t$. This is in fact the measure we will adopt when looking at large scale models, where the shock is sustained for several quarters. In all cases the interpretation is the same given in the text: the total (dollar or euro) change in investment (or consumption) following a shift in monetary policy relative to the total (dollar or euro) change in GDP (or domestic demand).

${ }^{9}$ One exception to this is when the persistence of the policy shift is significantly altered. However, this is unlikely to be the case for the kind of shifts that are considered throughout the paper. (See Angeloni et al. (2003) for further discussion on and comparison of these contribution statistics across countries.)
} 
compute the investment contribution (IC) not only comparing the investment response to the full response of GDP, but also comparing it to the changes in domestic demand (consumption plus investment).

In sum, the magnitudes of the $I C$ must be interpreted recognizing that the investment response we record is a conservative estimate of the IRC effects (since durable consumption and inventory investment are omitted, and government investment is included). This is obviously more of problem for the comparisons where investment movements are compared to investment plus consumption, since the misattribution of the durables responses is magnified in this case.

Moving to the results (Table 4) we note that, in the FRB-US model, consumption is responsible for the bulk of the GDP adjustment following an interest rate shock, both after one and three years, whereas in the AWM and in the NCB models, the contributions of consumption and investment are initially balanced, and at three years the latter dominates. In other words, it seems that in the transmission of monetary policy a relatively greater role is played by consumption in the U.S., and by investment in the euro area. This is consistent with the strength of wealth effects on consumer behavior in the U.S., as embodied in the FRB model ${ }^{10}$ (see Table 4 for the composition of the GDP response in VARs, and, Angeloni et al. (2003) and Angeloni, Kashyap and Mojon (2003) for deeper analyses of these results, together with robustness checks).

Overall, there is a large degree of correspondence between the estimates of the $I C$ coming from the VARs (neglecting Greece, Ireland and Austria, which produce the previously mentioned counter-intuitive results) and those coming from structural models. With the exception of France, in all the countries where meaningful comparisons can be made (Belgium, Germany, Finland, France, Italy, and Spain), accounting for over $85 \%$ of euro area GDP, the VARs and structural models yield broadly similar conclusions. However, it should be noted that for a few cases, the two measures of the contribution are rather different. When looking at structural model, in Belgium and Germany $I C$ is much larger when defined in terms of "consumption plus investment", while the opposite is true in Portugal. When looking at VARs, in Italy and Spain the contributions are much larger when defined in terms of GDP.

Turning to the specific countries, we judge aggregate demand shifts to be by and large dominated by investment in Austria, Finland, Ireland, Italy, Luxembourg, the Netherlands, and Spain. Investment contributions are somewhat smaller in Germany and much smaller in Greece. Finally, the French, Belgian, and Portuguese evidence is ambiguous. This (obviously subjective) 
assessment is reached by neglecting suspicious VAR results for Greece, Ireland, Austria and the Netherlands (see Figure 2) and by checking whether the majority of the reliable measures of the IC are above 60\%. Indeed, in Ireland, Italy, Luxembourg and Spain, the contribution of investment often accounts for more than $100 \%$ of the response of GDP. This is actually because net trade provides an offsetting contribution due to a sharp decline of imports. ${ }^{11}$ For Germany, model based simulations show a discrepancy between the contribution of investment to GDP (which is small) and to domestic demand (which is large). VAR based contributions are roughly consistent and point to a relatively small IC. For France, Belgium and Portugal the available measures of the IC are evenly split, some suggesting a large value and some a small one. We do not see any clear basis for deciding which assessment is more reliable.

Putting all this together, the evidence seems supportive of a dominant role of the investment in the transmission of monetary policy in 7 of the 12 euro area countries. The share of investment in the GDP response to monetary policy shocks is somewhat smaller in Germany, although it dominant in the structural models when seen relative to that of consumption. The situation in France, Belgium and Portugal is unclear. As mentioned in section 2, the key question becomes whether the strong observed investment responses are attributable to interest rates or are reflecting transmission via balance sheet, bank lending or other channels. We will address this question in the next section.

\section{Firm level estimates of the effect of interest rates on investment}

The aim of this section is to link the movements in investment to changes in interest rates - the direct test of the critical link in the IRC. The simultaneity problems that plague macroeconomic estimates of the interest sensitivity of investment can be partially overcome by relying instead on firm-level data. In particular, since the identification of the elasticity investment with respect to the user cost of capital in the micro data can be achieved through cross-firm variation in taxes and relative prices, the tendency of central banks to react to fluctuations in aggregate demand may not cause as much trouble for firm-level studies. That said, there are still plenty of challenges to consistently estimating this effect with micro data; see the thorough discussion on this point in Chatelain et al. (2003b).

\footnotetext{
${ }^{10}$ See, for example, Reifschneider, Tetlow and Williams (1999).

${ }^{11}$ The strong reaction of net trade results in surprisingly large investment contributions not only for very small and open economies such as Luxembourg and Ireland, but also in the VAR simulation for Spain and Italy (in the latter case, the structural model simulation confirms for year 3 after the shock also yields a very large IC)
} 
These challenges notwithstanding, we do not have any a priori reasons to suspect that these potential biases differ much across countries. Yet, there are countries where liquidity and cash-flow effects appear to be very important and countries where they appear hardly to matter. It is these differences, rather than the exact size of any coefficient estimates, that drive our assessment. In the next section we will attempt to cross-validate and to further qualify the conclusions that emerge from this analysis.

\subsection{Linking the policy rate to the determinants of investment}

In order to identify the full effects of monetary policy on investment, it is necessary to map the instrument controlled by the monetary authority into the determinants of investment. The investment equations that we rely upon, described in detail in Chatelain et al. (2003b), are specified so that firms' investment rate is determined by current and lagged values of sales growth, the growth of the user cost of capital, and the ratio of cash-flow to capital. Thus, our assessment depends on a set of estimates that relate the policy interest rate to sales, the user cost of capital, and cash-flow. ${ }^{12}$

We use aggregate data for Germany, France, Italy, and Spain to estimate these linkages. We computed the three determinants of investment in a similar way for each country, and then sought to correlate them with the relevant policy rate. We experimented with simple, single equation estimates and with VAR estimates obtained appending those variables to the VARs described in section 4. Fortunately, the three main conclusions presented below are relatively robust to these different approaches.

First, the user cost was most strongly affected by the policy rate in Spain, and its influence was fairly similar in the other three countries. Second, sales seemed to be well-described as a near random walk in each of the countries and there was a weak connection between the policy rate and sales. We view this conclusion as clearly unsatisfactory, most likely driven by the simultaneity between sales and interest rates, prominent in the aggregate data. However, while this might bias towards zero the measure of the overall interest rate elasticity of investment, it is unlikely to significantly affect our assessment of the relative role of cash-flow, which is our main focus of interest. Finally, the policy rate was more strongly related to cash-flow in Italy and to a

\footnotetext{
${ }^{12}$ There are several ways to establish the linkages between the policy rate and these variables, see Chatelain et al. (2003b) and Gaiotti and Generale (2003) two alternative strategies.
} 
lesser extent in France than in Spain or Germany. Changing the details of the regression specifications never changed the general properties of the linkages that we estimated.

For the other countries for which we have micro estimates of the investment equations (Belgium, Luxembourg, Austria and Finland), due to data shortages we calibrated the coefficients of the linkage equations to be the average values estimated for the other four countries, but also cross checked the results with other estimates of the linkages.

The elasticities of user cost, sales and cash-flow to the policy interest rate at years 1,2 and 3 (shown in Table 5) are used to combine the elasticity of investment to the user cost, to sales and to cash-flow, estimated on micro data, to get the overall elasticity of investment to the policy rate: we simulate the micro economic regression equations together with the linkage equations, assuming that the economies start in a steady state (that is consistent with the sample properties of the micro data sets) and are hit by an increase in the policy interest rate. We then compute the implied elasticity of investment.

Our assessment turns on the importance of cash-flow in the estimated investment elasticities. In particular, we compare the estimate of the overall elasticity when all the linkages between the policy rate and the determinants of investment are permitted and the estimate obtained when the cash-flow effects are suppressed. If the cash-flow effects are important in explaining the overall elasticity then we argue that the IRC does not provide a full explanation of the monetary transmission.

Importantly, for cash-flow effects to matter two conditions must hold. First, the cash-flow coefficients in the investment equation must be substantial. Second, the link between the policy rate and cash-flow must be significant. If either of these conditions fail then liquidity effects cannot play an important role in how monetary policy influences investment.

\subsection{Parsing the interest rate effects}

The elasticities of investment with respect to the policy rate (with and without cash-flow effects) are shown, for the 8 countries where we have micro-data based estimates, in Table 6 .

In Finland and Spain the pair of investment elasticities (overall and with cash-flow effects blocked out) are virtually identical. Also in Luxembourg, the role of the liquidity variable appears rather limited. This leads us to conclude that interest rate effects alone are responsible for the 
influence of the policy rate. Combined with our prior evidence, these countries appear to be cases where the IRC might be sufficient to explain monetary transmission.

Germany is a case, along with Greece, where the investment contributions to GDP responses were somewhat lower than for other countries. The data in Table 6 show that in Germany the cash-flow effects on investment are minimal. Similar conclusions are reached by von Kalckreuth (2003). While he finds that firms with a low credit score (as assigned by the Bundesbank) have a relatively high investment sensitivity to cash-flow, his calibrations suggest that these effects are not quantitatively large.

Overall, we conclude that for the purposes of modeling investment in Germany, the IRC is a satisfactory characterization, but that some non-interest channels could be operative for other components of spending. We will look for confirmation of this conjecture in the banking data. In particular, we will see whether bank lending to households is more importantly affected by monetary policy than elsewhere.

In Belgium and France the aggregate evidence previously examined was ambiguous regarding the role of investment. When looking at micro data, we see that in Belgium a sizeable part of the investment elasticity to the policy rate appears to operate through cash-flow effects. As the linkage equations were arbitrarily set equal to the average of the four main countries, we cross-checked this conclusion picking different sets of linkage coefficients. The result appears to be somewhat sensitive to the selection of the linkage equation, and in particular the role of cashflow appears substantially diminished assuming that the links are those estimated for Germany or Spain (the two countries where the interest rate elasticity of cash-flow is estimated to be the smallest). While this casts some doubts about the role of financial factors in Belgium, Butzen et al. (2003) find some evidence of a stronger effect of monetary policy on small firms, a finding usually interpreted as supportive of financial factors being at work in the transmission mechanism. Overall, we conclude that financial factors seem to matter for investment, and possibly for other components of GDP, given our agnostic conclusion about the aggregate role of investment in explaining aggregate demand movements.

As for France, Table 6 shows that the cash-flow effects are large, accounting for roughly half of the total investment response. Indeed, Chatelain and Tiomo (2003) find that adding cashflow to their equation eliminates the statistical significance of the user cost for their full sample of firms. These cash-flow effects, however, are not uniformly strong across all firms, with equipment producers showing the highest sensitivity. Collectively these findings suggest that interest rate 
induced changes in investment are unlikely to be the whole story in France. However, as in the case of Belgium, the prior ambiguity means that we cannot say whether any financial effects should be expected only for investment or for both investment and consumption.

Finally, Austria and Italy are cases where the IRC dominance was broadly consistent with the aggregate evidence on the composition of the output response but appears doubtful in light of the data in Table 6. In both these countries the cash-flow effects appear to be relatively large, possibly more important than the interest rate effects. As with Belgium, the results for Austria were cross-checked using alternative choices for the linkage equations. The relative importance of the liquidity measure remains sizeable even when picking the links estimated for Italy or Spain (where the interest elasticity of user cost is highest). In addition, Valderrama (2003) finds for Austria stronger effects of monetary policy on small and young firms, and smaller effects for firms that have a tighter credit relationship with a bank (hausbank). Both findings seem supportive of an important role of the credit channel in shaping the transmission of monetary policy. A similar supportive evidence for the role of financial factors is reported for Italy by Gaiotti and Generale (2003): they find that the effect of cash-flow on investment is stronger for small firms and for firms with a larger share of intangible assets. Overall, we provisionally conclude that financial factors, by influencing investment, appear to play, both in Italy and in Austria, a noticeable role in monetary transmission, and we will look for more evidence supporting this conclusion in the next section.

\section{The role of banks in the transmission of monetary policy}

To complete our assessment, we now examine the evidence on banks. While we have identified in a number of countries a role for financial factors, this does not necessarily imply a role for banks. Balance sheet or broad credit channel effects could be quite important. These balance sheet effects could operate in addition to any effects attributable to banks, or even in absence of effects generated by bank loan supply. The evidence that follows therefore can be viewed as a cross check to see whether the provisional assignments made in the last section should be refined to include a role for banks in the transmission mechanism.

In considering the refinement, we draw on three types of evidence. Whenever possible we rely on the findings of the country-specific, individual bank level analyses, abridged versions of which appear in Angeloni, Kashyap, and Mojon (2003). To succinctly summarise these findings, Table 7 reports a verbal description of their results. In cases where the country level data are 
missing or inconclusive we turn to two other sources. One piece, reported in Table 8, comes from expanding the VAR models estimated by Mojon and Peersman (2001) to include data on monetary aggregates, retail bank interest rates and bank loans. In some cases we also examine institutional features of the euro area national banking systems that might affect the strength of the bank lending channel. In particular, as emphasized by Ehrmann et al. (2003), four aspects could matter for monetary transmission: the importance of state influences in determining credit flows, the prevalence of relationship lending, the size of deposit insurance guarantees, and the extent of bank networks. We would expect that each of these features would reduce the sensitivity of bank lending to changes in monetary policy.

We begin by considering the countries for which the hypothesis of IRC dominance seemed to receive most support: Finland, Luxembourg and Spain. The two available country case studies on the bank lending channel (Topi and Vilmunen (2003) and Hernando and Martínez-Pagés (2003)) do not find clear evidence of loan supply effects on the monetary transmission. In the Spanish case this finding is reinforced by an interesting observation about the impact of the phenomenal growth of mutual funds in Spain. The deposit outflows that accompanied the growth were uneven across banks, but the lending changes that followed did not track the deposit shifts. This is unlikely to be due to any loan demand differences and is instead most naturally interpreted as showing that loan supply and deposits in Spain are not tightly linked. However, the structure of the Spanish banking system shows none of the institutional factors that might insulate lending decisions from monetary policy. In Finland, Topi and Vilmunen find that the main bank characteristics that might be expected to influence loan supply (size, capitalization and liquidity) do not lead to any significant differences. A limited role of bank supply in the transmission appears broadly consistent with the presence, in Finland, of an important network for the many co-operative banks.

In Italy and Austria the prior evidence identified financial factors as playing a role in explaining firms' responses to monetary policy. In Italy, the bank level analysis presented in Gambacorta (2003) indicates that monetary policy does alter loan supply. Specifically, he finds that the amount of liquidity on individual banks' balance sheets significantly influences the degree to which they change loans after a monetary shock: the lower the level of liquidity the stronger the loan supply response. Overall, these findings are consistent with previous results and the VAR evidence we examined. Indeed, Gambacorta (2001; Table 2) reports that there is near unanimity in the past literature that a broad credit channel exits. 
The Austrian evidence is more ambiguous. Kaufmann (2003) only finds cross bank differences in lending responses during recessions, when lending from banks with more liquid assets is significantly less affected than that from otherwise comparable banks. But the strength of this finding depends on how the recession periods are selected and also sometimes is accompanied by other anomalous findings (e.g. higher policy rates leading to higher lending). The VAR evidence does suggest that M1 and loans both contract after a monetary tightening. One possible explanation for the relatively weaker role of Austrian banks in the transmission process could be the importance of networks and relationship lending between firms and their banks.

Germany is the only country where our preliminary classification more clearly suggested that financial factors, if they were to matter, would operate through consumption, but not investment. Logically this would suggest investigating whether loan-supply effects (or other financial factors) are particularly important for households. We have no direct evidence on this question, but there are some suggestive pieces of information. First, the VARs shows that household borrowing falls much more quickly after a monetary tightening than does business borrowing. Actually, business borrowing is estimated to rise in the first year. Second, the bank level analysis of Worms (2003) shows significant loan supply effects that are related to the liquidity position of the banks. A relevant aspect of this paper is that it uses data on the customer mix of each bank to build a variable that reflects the average income of each bank's borrowers. As this income proxy should reliably control for loan demand, we expect lending changes to genuinely reflect supply shifts. At any rate, similar results are obtained when the standard controls for demand conditions employed by Ehrmann et al. (2003) are used. The general picture also seems to fit with certain structural features of Germany's banking system. On the one hand, the level of concentration is relatively low and banks are not particularly well capitalised. On the other hand, banks tend to belong to networks and the hausbank lending relations are often very strong. The latter feature could explain why corporate borrowers are insulated from credit restrictions, while households remain exposed.

In our preliminary classification Belgium was the country where it was unclear as to how much weight to assign to investment movements in accounting for GDP movements, but it was clear that cash-flow seemed important for observed investment responses. This suggests that liquidity effects would be expected to matter for business investment and possibly household expenditure. The VAR evidence, as in Germany, points to household borrowing responding much more quickly to a policy shift than business borrowing. As estimates based on bank level data are 
not available, we are not able to draw any strong conclusions for Belgium ${ }^{13}$. It is worth stressing however that de Bondt (2000) suggests that bank loan supply may be affected by monetary policy.

Based on the macro and the micro evidence on firms in France, financial factors appear to play an important role in driving investment responses to monetary policy. The French evidence on micro-bank data suggests that loan supply does shift when monetary policy changes. In particular, Loupias et al. (2003) show that less liquid French banks are more responsive to monetary policy. Previous studies using microeconomic data also find a role for banks - see Rosenwald (1998). The evidence does not speak to the question of whether the relative importance of these effects for business as opposed to consumer lending (both of which might be expected to matter based on the evidence in sections 4 and 5).

Finally, we are left with the four countries (Ireland, Greece, the Netherlands, and Portugal) where, absent firm-level evidence, our "testing" of the IRC dominance hypothesis was only partially, if at all, implementable.

Among these, Greece stands out because the small share of GDP movements accounted by investment already points at an important role for consumption adjustments in the transmission mechanism. This suggests looking for evidence of financial factors having a role for consumption (and possibly for investment). Brissimis et al. (2003) find that both smaller banks and banks with lower levels of liquidity are more responsive to monetary policy. Smaller banks, with less liquid assets are estimated to be especially sensitive to policy changes. However, we do not have enough information to tell whether these loan supply shifts are more relevant for households or businesses. Other evidence seems supportive of a non-negligible role of banks. ${ }^{14}$

In Portugal, the aggregate evidence was ambiguous about the role of investment. It appears that loan supply is affected by monetary policy changes. Farinha and Robalo (2003) conclude that bank capital plays an important role in shaping banks responses to monetary policy, with less capitalised banks being more sensitive. This is consistent with the institutional characteristics of

\footnotetext{
${ }^{13}$ The structural information is also ambiguous. On the one hand, the industry is concentrated (dominated by 12 banks) and the banks hold a relatively low percentage of assets in the form loans. On the other, the lack of relationship lending, government guarantees, deposit insurance and bank networks means that there are not some of the mechanisms that would cushion bank lending from monetary policy.

${ }^{14}$ For instance, the Greek banking system is characterised by banks holding relatively low levels of capital and liquid assets. Moreover neither networks nor relationship lending are believed to be significant. Finally, Brissimis and Kastrissianakis (1997) conclude that the bank lending channel appears to exist in Greece, although it may it have weakened in the 1990s.
} 
the banking sector in Portugal, whereby networks are unimportant and relationship lending is not typical, thus supporting the operation of a lending channel.

In the other two countries the aggregate evidence was broadly consistent with the hypothesis of IRC dominance (in the weak sense that investment appeared to be an important mover of aggregate demand responses to a monetary policy shift). In Ireland, we lack a bank level analysis and the indicators that are available provide ambiguous readings so that we draw no firm conclusions. $^{15}$

For the Netherlands, De Haan (2003) finds that unsecured bank lending is responsive to monetary policy. These effects are larger for small banks, banks with low liquidity and banks with low capital - although the interactions between these characteristics do not appear to be important. In contrast, secured lending seems to be unaffected by policy changes. Finally, household lending is little affected by policy changes, and this reinforces the view that monetary policy operates primarily by affecting investment. This relatively clear-cut evidence however contrasts with priors based on the fact that in the Dutch banking system liquidity, concentration and capital levels are relatively high and relationship lending is prevalent.

\section{Summary of the evidence for individual countries}

The logic of our "testing strategy" on how the macro-evidence, the firm level investment demand evidence and the bank level credit supply evidence affect the likelihood of IRC dominance leads to the two-way classification presented in Table 9.

\section{Austria}

Austria is a country where interest sensitive components of GDP seem to account for a large part of the movements of GDP in the wake of a monetary shock. But, firm-panel results show that there is a non-negligible role for liquidity variables in determining investment. Looking at the bank side, the results from the panel estimates suggest that the lending channel of monetary policy is not likely to be strong. This may be due to the strong bank networks and bank-firm relationships. Hence, any monetary policy effects beyond those going through the IRC should work largely through other channels (e.g., firm balance sheets).

\footnotetext{
${ }^{15}$ Bank networks are prominent, with most banks belonging to one, and there is a lot of relationship lending. But, the largest banks control a relatively small share of the total market, the share of loans in banks assets is very high, and banks do not seem to carry high levels of liquidity or capital.
} 


\section{Belgium}

The evidence appears to point against IRC dominance in Belgium. The VAR and the structural models provide conflicting indications about the role of investment in accounting for aggregate demand movements (small when considering GDP, large when considering domestic demand). The evidence on investment is that financial factors probably matter for investment. On the bank side, previous evidence concluded that the role of bank loan supply shifts seem to play a role in the transmission of monetary policy in Belgium. We have no evidence that can be used to challenge that finding.

\section{Finland}

In Finland, the IRC seems to offer a satisfactory account of monetary transmission. The VAR and national econometric model suggest that this would be the case and we find the microeconomic evidence on investment to be consistent with this prediction as well. The prior banking evidence available on Finland was very limited. Our bank panel estimates (from the post-banking crisis period) signal that loan supply does not appear to be very responsive to monetary policy. In any case, considering that the IRC seems to be dominant, loan supply behaviour of banks should not play an important role ${ }^{16}$ in the overall mechanism.

\section{France}

As in Belgium, we had difficulty getting for France a consistent assessment of the role of interest sensitive spending components. Traditionally, it has been difficult to identify cost of capital effects on investment in France. Our evidence confirms that, in keeping with the findings of past studies, the cost of capital does not have a strong effect on investment, while financial factors - as captured by a cash-flow variable - appear important. On the bank side, the earlier literature placed France, alongside with Germany and Italy, among the candidates for a strong bank lending channel. The evidence we have does not fully confirm this. Bank liabilities do not appear to be strongly affected by monetary policy; however, loan rates react strongly to monetary policy. The panel evidence on banks suggests that loans supply is responsive to monetary policy.

\section{Germany}

The German evidence is also complicated. On the one hand, investment spending plays a smaller than average role in accounting for GDP movements in the wake of a monetary policy

\footnotetext{
${ }^{16}$ Our main caveat surrounding this conclusion is that much of the evidence comes in the post banking crisis environment. Some prior studies had found that liquidity variables might matter for investment. We leave open the possibility that this may be the case again now that the adjustment to the crisis is over.
} 
shift. On the other hand, the IRC seems to be the dominant, indeed almost the only relevant channel in explaining monetary policy effects on investment. At the same time, the monetary shifts appear to alter loan supply. One possible reconciliation is that loan supply effects influence consumption, but cannot be independently checked using the evidence in this book.

\section{Greece}

The large changes in the Greek economy over the last decade make it difficult for us to fit a stable VAR. But, based on the structural model of the Greek economy, it appears that consumption is an important component of the adjustment to a monetary shock. Earlier authors have pointed at Greece as a candidate for significant loan supply effects, and the new econometric evidence we quoted points in this direction.

\section{Ireland}

Ireland is the country where our evidence on monetary transmission is scarcest. The only available one comes from the structural model of the economy and it suggests that the IRC could be quite important. But we lack any findings about firms or banks that allow us to test this conjecture.

Italy

Interest sensitive spending in Italy seems to largely account for output movements in the wake of a monetary policy shift. The investment response, however, shows clear signs of being affected by financial factors. This seems to reject the IRC dominance. Moreover, bank lending responds to policy shifts. This picture is confirmed by a host of studies. Overall Italy is a country where the case for the presence of lending channel seems strong.

\section{Luxembourg}

Our evidence for Luxembourg is somewhat incomplete. We do not have the data needed to fit a VAR, so relying solely on the structural econometric model we conclude that interest sensitivity spending movements dominate the monetary induced changes in GDP. The firm level evidence moreover suggests that investment does not appreciably depend on firms' liquidity holdings. The (limited) previously available evidence for Luxembourg suggests that bank loan supply is not likely to play a major role in monetary transmission. Our informal evidence supports this, though we lack any econometric evidence on bank behaviour in Luxembourg. 


\section{Netherlands}

We also have incomplete information on the Netherlands. The VAR and econometric model each suggest that the investment plays an important role in accounting for output responses to monetary policy, but we lack the firm level analysis to verify whether this corresponds to a dominant IRC. Past evidence is ambiguous as to whether investment responses can be fully explained by interest rate effects. There is clear evidence that bank loan supply changes following changes in monetary policy. The extension of household credit, however, does not appear affected. Thus, the outstanding question is whether the estimated change in unsecured business credit is relevant for Dutch corporate investment.

\section{Portugal}

As with Greece, Ireland and the Netherlands, the assessment of Portugal is impaired by lack of data. The structural changes in the economy limit our ability to estimate a VAR, while the evidence based on the econometric model was ambiguous about the role of investment. We lack the firm level evidence needed to further sharpen this assessment. However, it appears that bank loan supply does change following a shift in monetary policy. As in the Netherlands, we cannot determine whether this is material for the transmission.

Spain

Spain is the case where the evidence most consistently points towards a pure IRC explanation for monetary transmission. Following a monetary policy shift, investment movements are substantial, yet they do not appear to be dependent on financial factors. Loan supply also appears to be disconnected from monetary policy; the evidence on how banks also shielded their lending after regulatory induced deposit outflows reinforces this presumption. This all fits together and suggests that financial factors do not play an important role in the Spanish monetary transmission.

\section{Conclusions}

Taken together, the findings from this project paint a rich, composite and, to some extent, surprising picture of the monetary transmission for the euro area as a whole. This picture can hopefully also serve as a point of departure when sufficient information to document, and measure, any changes in the transmission process resulting from the introduction of the single currency becomes available. 
Starting with the unsurprising aspects, the VAR analysis suggests that an unexpected increase in the short-term interest rate temporarily reduces output, with the peak effects occurring after roughly one year. Prices respond more slowly, with inflation hardly moving during the first year and then falling gradually over the next few years. Structural econometric models, though not strictly comparable, provide a picture with similar qualitative features. Despite the somewhat artificial nature of the synthetic data for the area as a whole, these findings are theoretically sensible and broadly consistent with a large body of empirical literature analyzing either individual countries of the euro area or the other large currency area in the world, namely the U.S. Moreover, the delayed response of prices relative to that of output suggests that studying the transmission of policy to spending and output is a logical step, even if the aim of monetary policy is defined primarily or exclusively in terms of prices.

A further aspect of the assessment based on aggregate data at the area level is that both the VARs and the structural models highlight the importance of investment in driving output changes in the wake of a monetary policy tightening. This feature distinguishes the transmission mechanism in the euro area from that in the U.S., where much of the output adjustment appears to be due to changes in consumption - a topic we explore further in Angeloni et al. (2003).

Moving to the question posed in our title, the answer seems to be no. Neither the IRC nor a broadly construed financial channel emerges as clearly and exclusively dominant. Although somewhat obvious, this conclusion contradicts both the presumption of an IRC dominance based on the just mentioned, quantitatively large role of interest sensitive spending in explaining output movements, and the presumption of a strong and widespread lending channel based on the overarching role of banks as providers of finance in the euro area. While making a precise quantitative estimate of the contributions of each channel is not yet possible at this stage, we can nonetheless further qualify the overall picture in several ways.

First, while not dominant on the whole, the IRC is still a prominent channel in the transmission. For the euro area as a whole, the interest sensitive demand components account for the bulk of the change in GDP after a monetary policy shift. Moreover, in a group of countries, accounting for about $15 \%$ of the euro area GDP, the IRC is unambiguously the dominant channel. In all other countries for which we have the evidence (covering, together with the first group, about $90 \%$ of the euro area GDP) interest rate effects are always a sizeable, and sometimes the virtually unique, source of investment movements. It is interesting that there generally seems to be a significant effect of the user cost of capital on investment. This finding, based on a careful 
analysis of micro level data, is somewhat in contrast with the often more ambiguous results coming from aggregate data.

Second, financial factors influence the transmission of monetary policy in several ways. Importantly, the cases where the IRC dominance do not find much support do not point to a single, prevalent alternative. In some of the countries it looks like the role of banks in supplying business credit to finance investment may be important. But this does not appear to hold everywhere, as there are cases in which if loan supply matters it is not likely to be true for investment. Thus, in terms of monitoring bank lending it is probably necessary to track both household and business lending. Moreover, there are also cases in which financial factors are important but banks are not likely to be an important ingredient in the picture.

Thirdly, the overall role of banks in the transmission mechanism is somewhat different, and perhaps smaller, than what might have been expected based on prior work. There are countries where bank lending appears irrelevant for transmission. In some, we suspect that government guarantees to support banks, the propensity of banks to operate in networks, and strong borrower-lender relationships may mitigate the strength of any loan supply effects. Taken together this means that even though the banks dominate the supply of credit in all euro area countries, they do not appear to be uniformly important.

Lastly, in assessing the role that the banks do play in the transmission, the relevant characteristics that appear to affect the potency of the lending channel are not always those that we (and probably others too, based on our reading of the past literature) would have guessed. Bank size and bank capital seems not to play much of role in shaping loan supply responses to monetary policy. We find the institutional reasons discussed by Ehrmann et al. (2003), and noted in section 6 , to be a plausible explanation for this result. But this means that the vast heterogeneity in terms of size both across and within countries is probably not very important. In contrast, bank liquidity positions seem to be important in virtually all the countries where loan supply effects appear to be present. But there are other potential supply effects that remain to be isolated.

All of our analysis has been based on the analysis of data from before the launch of the euro. Capital markets, bank market structure, and business financing already have changed substantially over the last four years. One obvious caveat to our analysis is that we cannot say whether this has changed the operation of the monetary policy transmission channels, as a result e.g. of increased monetary and financial integration. Angeloni and Ehrmann (2003) explore these issues by looking at post 1999 data. 
Whether or not our assessments are confirmed in future work, we believe that they still provide guidance about useful next steps in studying monetary transmission in the euro area. For instance, it would be very useful to fill in the missing pieces of evidence that would be needed to complete and make more robust our analysis for all the countries. In particular, being able to gauge the macroeconomic importance of the lending supply effects in those countries where our evidence confirms their presence would be very important. Also, for several of the countries the implication of the analysis is that consumption adjustment is surprisingly important for transmission. Compiling direct evidence on this is another obvious next step. 


\section{Bibliography}

Agresti A. and B. Mojon (2003), Some stylised facts on the euro area business cycle, Chapter 1, in I. Angeloni, A. Kashyap and B. Mojon (eds.) Monetary Transmission in the Euro Area, Cambridge University Press.

Angeloni, I. and M. Ehrmann (2003), Monetary transmission in the euro area: early evidence. Forthcoming in Economic Policy 37 (October).

Angeloni, I., A. Kashyap, B. Mojon and D. Terlizzese (2003), The output-composition puzzle: a difference in the monetary transmission mechanism in the euro area and the U.S. Forthcoming: Journal of Money, Credit and Banking.

Angeloni, I., A. Kashyap and B. Mojon (eds.) (2003), Monetary Transmission in the Euro Area, Cambridge University Press.

Brissimis S. and Kastrissianakis (1997), Is there a credit channel in the Greek economy? , Bank of Greece Economic Bulletin, 10.

Brissimis S., N. Kamberoglou and G. Simigiannis (2003), Is there a bank-lending channel of monetary policy in Greece? Evidence from bank-level data, Chapter 18, in I. Angeloni, A. Kashyap and B. Mojon (eds.) Monetary Transmission in the Euro Area, Cambridge University Press.

Butzen P., C. Fuss and P. Vermeulen (2003), Business investment and monetary transmission in Belgium, Chapter 8, in I. Angeloni, A. Kashyap and B. Mojon (eds.) Monetary Transmission in the Euro Area, Cambridge University Press.

Chatelain J.-B. and A. Tiomo (2003), Monetary policy and corporate investment in France, Chapter 10, in I. Angeloni, A. Kashyap and B. Mojon (eds.) Monetary Transmission in the Euro Area, Cambridge University Press.

Chatelain J.- B., M. Ehrmann, A. Generale, J. Martínez-Pagés, P. Vermeulen and A. Worms (2003a), Monetary policy transmission in the euro area: new evidence from micro data on firms and banks, Journal of the European Economic Association 1 (2-3) April-May.

Chatelain J.-B., A. Generale, I. Hernando, U. von Kalckreuth and P. Vermeulen (2003b), Firm investment and monetary policy transmission in the euro area, Chapter 7, in I. Angeloni, A. Kashyap and B. Mojon (eds.) Monetary Transmission in the Euro Area, Cambridge University Press.

Christiano, L., M. Eichenbaum and C. Evans (1999), Monetary Shocks: what have we learned and to what end?, Chapter 2, in John Taylor and Michael Woodford (eds.) The Handbook of Macroeconomics, Elsevier Science Publication.

De Haan L. (2003), The impact of monetary policy on bank-lending in the Netherlands, Chapter 20, in I. Angeloni, A. Kashyap and B. Mojon (eds.) Monetary Transmission in the Euro Area, Cambridge University Press.

De Bondt G. (2000), Financial Structure and the transmission mechanism in Europe: a crosscountry study, Edward Elgar, Cheltenham, UK. 
Ehrmann M., L. Gambacorta, J. Martínez-Pagés, P. Sevestre, A. Worms (2003), Financial systems and the role of banks in monetary policy transmission in the euro area, Chapter 14, in I. Angeloni, A. Kashyap and B. Mojon (eds.) Monetary Transmission in the Euro Area, Cambridge University Press.

Els P. van, A. Locarno, B. Mojon and J. Morgan (2003a), New macroeconomic evidence on monetary policy transmission in the euro area, Journal of the European Economic Association, April-May, Vol. 1 (2-3).

Els P. van, A. Locarno, J. Morgan and J-P. Villetelle (2003b), The effects of monetary policy in the euro area: evidence from structural macroeconomic models, Chapter 5, in I. Angeloni, A. Kashyap and B. Mojon (eds.) Monetary Transmission in the Euro Area, Cambridge University Press.

Fagan G., J. Henry and R. Mestre (2001) An area-wide model (AWM) for the euro area, ECB Working Paper 42.

Farinha L. and C. Robalo (2003), The bank-lending channel of monetary policy: identification and estimation using Portuguese micro bank data, Chapter 22, in I. Angeloni, A. Kashyap and B. Mojon (eds.) Monetary Transmission in the Euro Area, Cambridge University Press.

Gaiotti E. and A. Generale (2003), Monetary policy and firms' investment in Italy, Chapter 11, in I. Angeloni, A. Kashyap and B. Mojon (eds.) Monetary Transmission in the Euro Area, Cambridge University Press.

Gambacorta L. (2003), The Italian banking system and monetary policy transmission: evidence from bank-level data, Chapter 19, in I. Angeloni, A. Kashyap and B. Mojon (eds.) Monetary Transmission in the Euro Area, Cambridge University Press.

Gambacorta L. (2001), bank specific characteristics and monetary policy transmission: the case of Italy, ECB Working Paper No. 103.

Hernando I. and J. Martínez-Pagés (2003), Is there a bank-lending channel of monetary policy in Spain?, Chapter 16, in I. Angeloni, A. Kashyap and B. Mojon (eds.) Monetary Transmission in the Euro Area, Cambridge University Press.

Kalckreuth U. von (2003), Investment and monetary transmission in Germany: a microeconometric investigation, Chapter 9, in I. Angeloni, A. Kashyap and B. Mojon (eds.) Monetary Transmission in the Euro Area, Cambridge University Press.

Kaufmann S. (2003), The cross-sectional and the time dimension of the bank-lending channel: the Austrian case, Chapter 21, in I. Angeloni, A. Kashyap and B. Mojon (eds.) Monetary Transmission in the Euro Area, Cambridge University Press.

Loupias C., F. Savignac and P. Sevestre (2003), Is there a bank-lending channel in France? Evidence from bank panel data, Chapter 17, in I. Angeloni, A. Kashyap and B. Mojon (eds.) Monetary Transmission in the Euro Area, Cambridge University Press.

Lünnemann P. and T. Mathä (2001), Monetary transmission: empirical evidence from Luxembourg firm-level data, ECB Working Paper No. 111.

McAdam P. and J. Morgan (2003), Analysing monetary policy transmission at the euro area level using structural macroeconomic models, Chapter 4, in I. Angeloni, A. Kashyap and B. Mojon (eds.) Monetary Transmission in the Euro Area, Cambridge University Press.

Mojon B. and G. Peersman (2003), A VAR description of the effects of monetary policy in the individual countries of the euro area, Chapter 3, in I. Angeloni, A. Kashyap and B. Mojon (eds.) Monetary Transmission in the Euro Area, Cambridge University Press, 2003. 
Mojon B. and G. Peersman (2001), A VAR description of the effects of monetary policy in the individual countries of the euro area, ECB Working Paper 92.

Peersman G. and F. Smets (2003), The monetary transmission mechanism in the euro area: evidence from VAR analysis, Chapter 2, in I. Angeloni, A. Kashyap and B. Mojon (eds.) Monetary Transmission in the Euro Area, Cambridge University Press.

Reifschneider, D., R. Tetlow and J. Williams (1999), Aggregate disturbances, monetary policy and the macroeconomy: the FRB/US perspective, Federal Reserve Bulletin (January).

Topi J. and J. Vilmunen (2003), Transmission of monetary policy shocks in Finland: evidence from bank-level data on loans, Chapter 23, in I. Angeloni, A. Kashyap and B. Mojon (eds.) Monetary Transmission in the Euro Area, Cambridge University Press.

Valderrama M-T. (2003), The role of trade credit and bank-lending relationships in the transmission mechanism in Austria, Chapter 13, in I. Angeloni, A. Kashyap and B. Mojon (eds.) Monetary Transmission in the Euro Area, Cambridge University Press.

Valderrama M-T. (2001), Credit channel and investment behavior in Austria: a micro-econometric approach, ECB Working Paper No. 108.

Worms A. (2003), The reaction of bank-lending to monetary policy measures in Germany, Chapter 15, in I. Angeloni, A. Kashyap and B. Mojon (eds.) Monetary Transmission in the Euro Area, Cambridge University Press. 
Figure 1: The effects of monetary policy shocks in the euro area and the United States (Estimation period: 1980-1998)
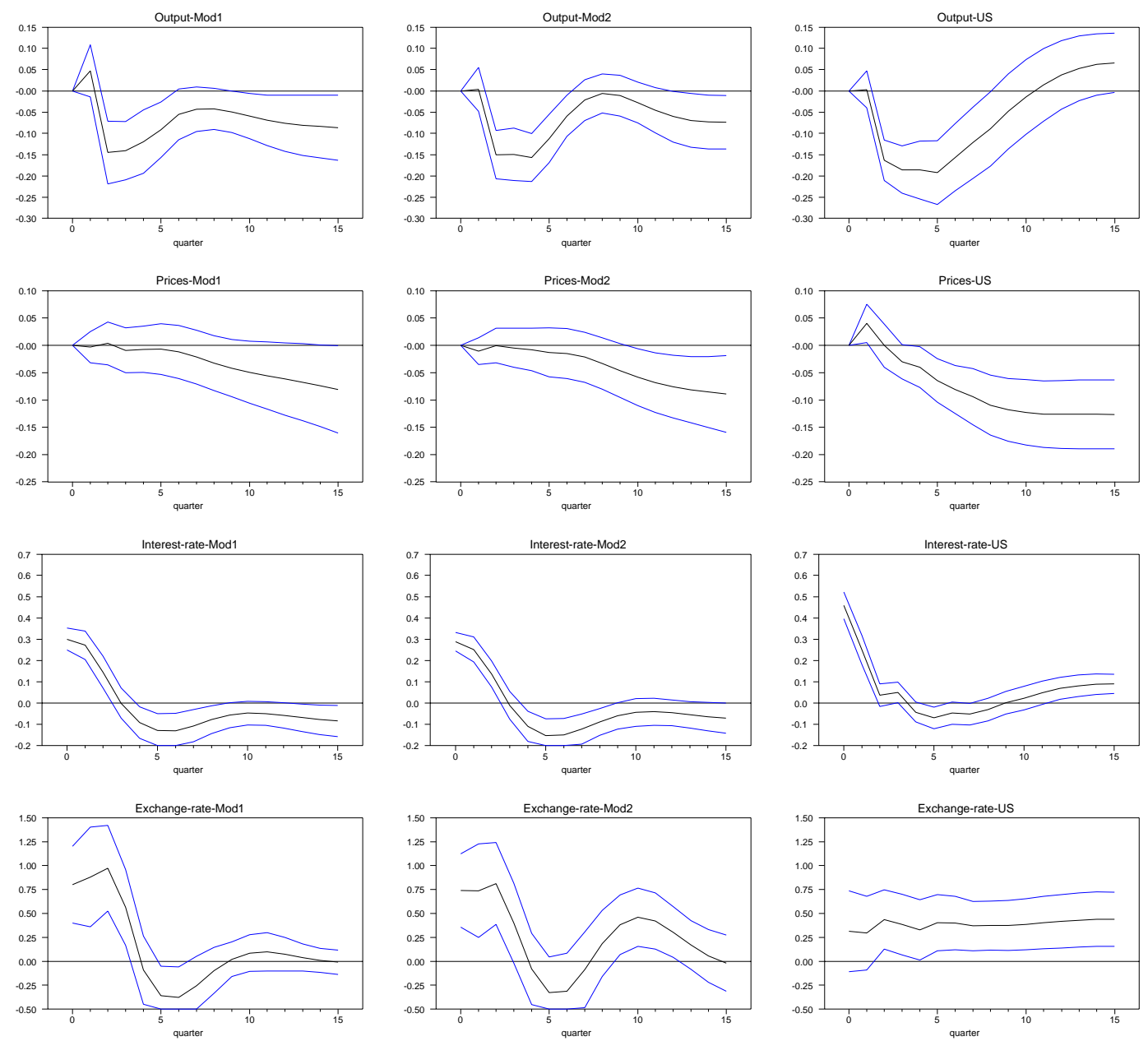

Note: Source is Peersman and Smets (2003). Mean responses and $90 \%$ confidence bands are shown. 
Figure 2: Country level estimates of monetary policy shocks
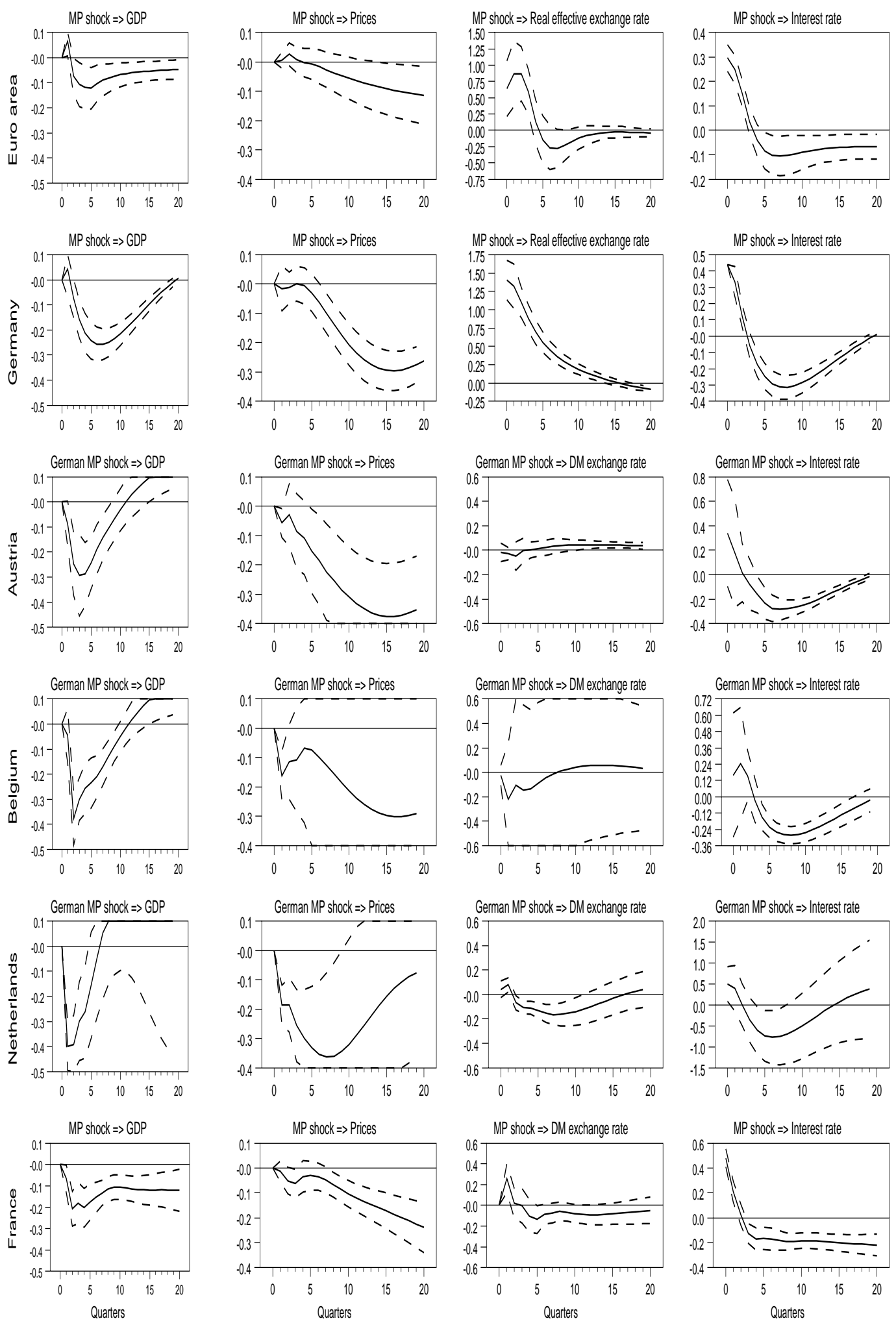

Notes: Source is Mojon and Peersman (2003), dotted lines $=0.05$ and 0.95 percentiles; solid line $=$ impulse responses. 
Figure 2: Country level estimates of monetary policy shocks, continued
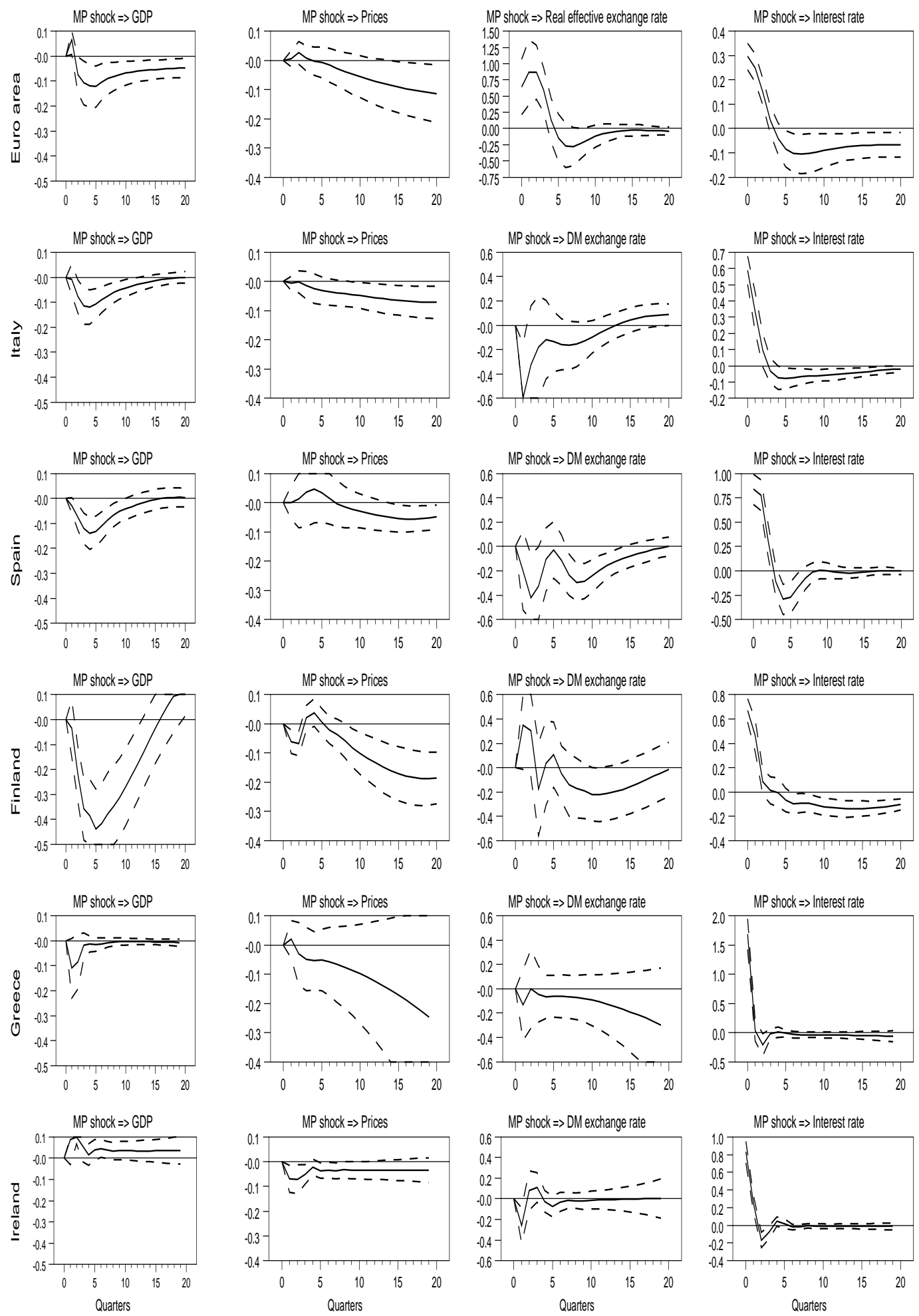

Notes: Source is Mojon and Peersman (2003), dotted lines = 0.05 and 0.95 percentiles; solid line = impulse responses. 
Table 1: Effects of monetary policy shocks in large scale models (deviation from baseline in \%)

\begin{tabular}{|c|c|c|c|c|c|c|c|c|c|}
\hline \multirow{3}{*}{ Models } & \multirow{2}{*}{\multicolumn{3}{|c|}{$\frac{\text { U.S. }}{\text { FRB-US }}$}} & \multicolumn{6}{|c|}{ Euro area } \\
\hline & & & & \multicolumn{3}{|c|}{$\mathrm{NCBs}$} & \multicolumn{3}{|c|}{ AWM } \\
\hline & Year 1 & Year 2 & Year 3 & Year 1 & Year 2 & Year 3 & Year 1 & Year 2 & Year 3 \\
\hline Short-term rate & 1.00 & 1.00 & 0.00 & 1.00 & 1.00 & 0.00 & 1.00 & 1.00 & 0.00 \\
\hline Long term rate & 0.16 & 0.06 & 0.00 & 0.16 & 0.06 & 0.00 & 0.16 & 0.06 & 0.00 \\
\hline Effective exchange rate & 1.60 & 0.63 & 0.00 & 1.60 & 0.63 & 0.00 & 1.60 & 0.63 & 0.00 \\
\hline CPI & -0.07 & -0.41 & -1.01 & -0.09 & -0.21 & -0.31 & -0.15 & -0.30 & -0.38 \\
\hline GDP & -0.35 & -1.28 & -1.37 & -0.22 & -0.38 & -0.31 & -0.34 & -0.71 & -0.71 \\
\hline Consumption & -0.37 & -1.35 & -1.44 & -0.12 & -0.23 & -0.19 & -0.27 & -0.58 & -0.54 \\
\hline Investment & -0.31 & -1.79 & -3.16 & -0.34 & -1.04 & -1.22 & -0.81 & -2.37 & -2.96 \\
\hline
\end{tabular}

Sources: Euro area, van Els et al (2003b); U.S., private correspondence with Flint Brayton.

Table 2: Effects of an exchange rate sustained shocks on the euro area and the U.S. (deviation from baseline in \%)

\begin{tabular}{|c|c|c|c|c|c|c|c|c|c|}
\hline \multirow{3}{*}{ Models } & \multirow{2}{*}{\multicolumn{3}{|c|}{$\begin{array}{c}\text { U.S. } \\
\text { FRB-US }\end{array}$}} & \multicolumn{6}{|c|}{ Euro area } \\
\hline & & & & \multicolumn{3}{|c|}{ NCBs } & \multicolumn{3}{|c|}{ AWM } \\
\hline & Year 1 & Year 2 & Year 3 & Year 1 & Year 2 & Year 3 & Year 1 & Year 2 & Year 3 \\
\hline Effective exchange rate & 5.00 & 5.00 & 5.00 & 5.00 & 5.00 & 5.00 & 5.00 & 5.00 & 5.00 \\
\hline CPI & -0.07 & -0.33 & -0.44 & -0.18 & -0.34 & -0.53 & -0.37 & -0.78 & -1.08 \\
\hline GDP & -0.05 & -0.52 & -1.01 & -0.27 & -0.36 & -0.43 & -0.47 & -0.96 & -1.24 \\
\hline Consumption & 0.04 & -0.04 & -0.33 & -0.01 & -0.02 & -0.03 & -0.28 & -0.72 & -1.02 \\
\hline Investment & 0.06 & -0.39 & -1.40 & -0.19 & -0.46 & -0.48 & -0.49 & -1.20 & -1.71 \\
\hline
\end{tabular}


Table 3: Cross-country evidence on the effects of monetary policy

NCBs structural models

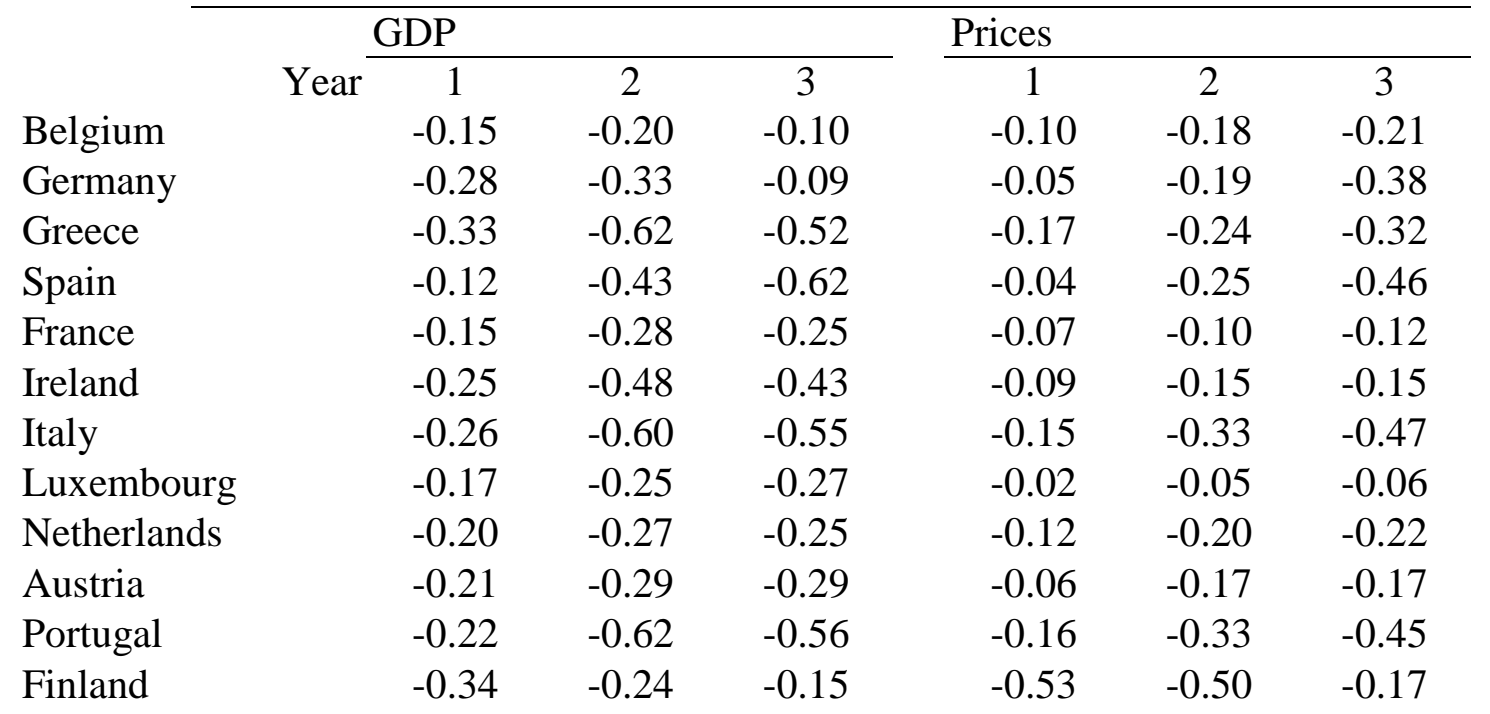

VARs

\begin{tabular}{|c|c|c|c|c|c|c|}
\hline \multicolumn{4}{|c|}{ GDP } & \multicolumn{3}{|l|}{ Prices } \\
\hline Year & 1 & 2 & 3 & 1 & 2 & 3 \\
\hline & -0.18 & -0.22 & -0.07 & -0.10 & -0.09 & -0.20 \\
\hline & -0.05 & -0.24 & -0.22 & -0.01 & -0.05 & -0.19 \\
\hline & -0.05 & -0.01 & 0.00 & -0.01 & -0.06 & -0.09 \\
\hline & -0.06 & -0.12 & -0.05 & 0.01 & 0.02 & -0.03 \\
\hline & -0.11 & -0.17 & -0.11 & -0.03 & -0.04 & -0.09 \\
\hline & 0.09 & 0.04 & 0.03 & -0.05 & -0.03 & -0.03 \\
\hline & -0.05 & -0.10 & -0.05 & -0.01 & -0.03 & -0.05 \\
\hline &.. &.. &.. &.. & . & .. \\
\hline & -0.27 & -0.10 & 0.22 & -0.16 & -0.34 & -0.33 \\
\hline & -0.16 & -0.22 & -0.05 & -0.04 & -0.17 & -0.30 \\
\hline & .. & .. & .. & .. & .. & .. \\
\hline & -0.15 & -0.40 & -0.29 & -0.03 & 0.00 & -0.09 \\
\hline
\end{tabular}

Sources: The NCB model simulation results are based on van Els et al. (2003b); the VAR results are based on Mojon and Peersman (2003). The VAR results show the effects of a one standard deviation shock to the interest rate.

Note: .. not available. 
Table 4: Contribution of investment to aggregate demand

\begin{tabular}{|c|c|c|c|c|c|c|}
\hline \multicolumn{4}{|c|}{$\begin{array}{c}\text { Based on NCBs structural models } \\
\text { I/GDP }\end{array}$} & \multicolumn{3}{|c|}{$\mathrm{I} /(\mathrm{C}+\mathrm{I})$} \\
\hline Quarters & 4 & 8 & 12 & 4 & 8 & 12 \\
\hline Belgium & 0.43 & 0.39 & 0.41 & 1.31 & 1.36 & 1.43 \\
\hline Germany & 0.14 & 0.16 & 0.19 & 0.69 & 0.74 & 1.00 \\
\hline Greece & 0.20 & 0.48 & 0.55 & 0.24 & 0.42 & 0.45 \\
\hline Spain & 1.14 & 0.97 & 0.90 & 0.91 & 0.78 & 0.73 \\
\hline France & 0.16 & 0.23 & 0.24 & 0.21 & 0.27 & 0.27 \\
\hline Ireland & 0.86 & 1.69 & 1.29 & 0.64 & 0.85 & 0.85 \\
\hline Italy & 0.48 & 0.91 & 1.12 & 0.57 & 0.77 & 0.86 \\
\hline Luxembourg & 0.18 & 2.34 & 1.75 & 1.00 & 0.87 & 0.89 \\
\hline Netherlands & 0.50 & 0.72 & 0.74 & 0.72 & 0.80 & 0.67 \\
\hline Austria & 0.76 & 0.78 & 0.72 & 0.79 & 0.64 & 0.53 \\
\hline Portugal & 0.93 & 0.90 & 0.76 & 0.40 & 0.49 & 0.42 \\
\hline Finland & 0.50 & 0.58 & 0.66 & 0.70 & 1.54 & 0.88 \\
\hline Euro area aggregate & 0.33 & 0.55 & 0.68 & 0.57 & 0.66 & 0.67 \\
\hline Euro area AWM & 0.61 & 0.81 & 0.86 & 0.45 & 0.59 & 0.68 \\
\hline US & 0.15 & 0.23 & 0.33 & 0.19 & 0.26 & 0.34 \\
\hline
\end{tabular}

Based on VARs

\begin{tabular}{lccccccc}
\multicolumn{1}{c}{ Quarters } & \multicolumn{3}{c}{$\mathrm{I} / \mathrm{GDP}$} & & \multicolumn{3}{c}{$\mathrm{I} /(\mathrm{C}+\mathrm{I})$} \\
\cline { 2 - 4 } \cline { 7 - 8 } Belgium & 0.24 & 0.52 & 0.64 & & 0.93 & 0.66 & 0.60 \\
Germany & 0.52 & 0.44 & 0.37 & & 0.52 & 0.53 & 0.47 \\
Greece & -0.18 & -0.11 & -0.12 & & -0.35 & -0.24 & -0.21 \\
Spain & 1.33 & 1.13 & 0.98 & & 0.55 & 0.56 & 0.55 \\
France & 0.89 & 0.81 & 0.73 & & 0.76 & 0.68 & 0.63 \\
Ireland & -0.21 & -0.32 & -0.28 & & 0.48 & 0.65 & 0.77 \\
Italy & 1.02 & 0.99 & 0.92 & & 0.37 & 0.38 & 0.36 \\
Luxembourg &.. &.. &.. & &.. &.. &.. \\
Netherlands & 0.45 & 0.54 & 0.36 & & 0.59 & 0.86 & -0.49 \\
Austria & 0.15 & -0.02 & -0.01 & & 0.95 & -0.07 & -0.01 \\
Portugal &.. &.. &.. & &.. &.. &.. \\
Finland & 0.50 & 0.65 & 0.77 & & 0.60 & 0.58 & 0.58 \\
Euro area aggregate & 0.75 & 0.69 & 0.62 & & 0.57 & 0.53 & 0.42 \\
Euro area VAR & 1.89 & 0.99 & 0.71 & & 0.78 & 0.67 & 0.65 \\
US & 0.42 & 0.53 & 0.51 & & 0.32 & 0.44 & 0.42
\end{tabular}

Sources: NCBs structural models, van Els et al. (2003b); VARs, Mojon and Peersman (2003).

Note: The contribution is equal to the ratio of the relative deviations from baseline of investment to either GDP or consumption plus investment $(\mathrm{C}+\mathrm{I})$, times the average share of investment relative to GDP (relative to $\mathrm{C}+\mathrm{I}$ ). In the case of the VARs, where the shock is one-off, the deviations from baseline are cumulated (up to quarter 4,8 and 12). Structural model simulations were transformed in order top recover the effect of a interest rate shock sustained for 12 quarters. U.S. VARs correspond to the Christiano et al (1999) baseline model augmented with consumption and investment (see Angeloni, Kashyap and Mojon, 2003, for an illustration). Euro area aggregate is the weighted average of country results, using PPP 1995 GDP weights.

.. : not available. 
Table 5: Elasticities of investment determinants with respect to the policy rate
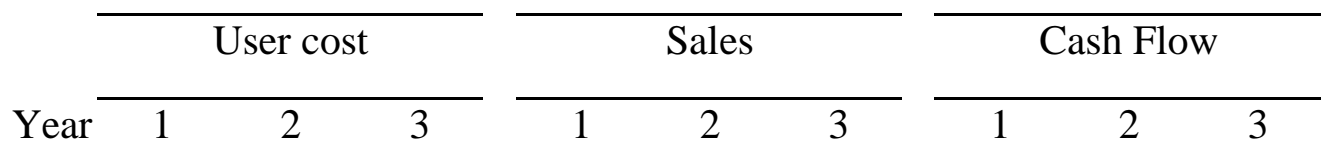

\begin{tabular}{lccccccccc} 
Germany & 0.14 & 0.17 & 0.18 & 0.04 & 0.04 & 0.03 & 0.00 & -0.15 & -0.24 \\
France & 0.18 & 0.29 & 0.26 & 0.0 & -0.03 & -0.09 & -0.21 & -0.27 & -0.40 \\
Italy & 0.24 & 0.29 & 0.27 & 0.0 & -0.07 & -0.09 & -0.36 & -0.80 & -0.59 \\
Spain & 0.39 & 0.56 & 0.57 & -0.02 & -0.02 & -0.03 & -0.03 & -0.07 & -0.11 \\
\hline
\end{tabular}

For the description of the main features of the equations underlying this table, see the main text. 
Table 6: Elasticities of investment with respect to the policy rate

\begin{tabular}{llccc}
\hline \multirow{2}{*}{ Germany } & Year & 1 & 2 & 3 \\
\cline { 2 - 4 } Spain & Full elasticity (1) & -0.13 & -0.18 & -0.16 \\
& Elasticity suppressing cash flow (2) & -0.13 & -0.17 & -0.14 \\
Finland & Full elasticity (1) & -0.58 & -0.45 & -0.15 \\
& Elasticity suppressing cash flow (2) & -0.57 & -0.46 & -0.17 \\
Luxembourg *\# & -0.01 & -0.03 & -0.09 \\
& Full elasticity (1) & -0.01 & -0.03 & -0.07 \\
France & Elasticity suppressing cash flow (2) & -0.57 & -0.29 & -0.10 \\
\multirow{3}{*}{ Italy } & Full elasticity (1) & -0.57 & -0.17 & 0.00 \\
& Elasticity suppressing cash flow (2) & -0.03 & -0.15 & -0.22 \\
Belgium & Full elasticity (1) & 0.00 & -0.05 & -0.06 \\
& Elasticity suppressing cash flow (2) & -0.30 & -0.54 & -0.43 \\
Austria * & Full elasticity (1) & -0.15 & -0.21 & -0.15 \\
& Elasticity suppressing cash flow (2) & -0.02 & -0.09 & -0.15 \\
& Full elasticity (1) & -0.01 & -0.04 & -0.05 \\
& Elasticity suppressing cash flow (2) & -0.57 & -0.46 & -0.34 \\
& Full elasticity (1) & -0.25 & -0.14 & -0.04 \\
& Elasticity suppressing cash flow (2) & &
\end{tabular}

Notes: For each country, the entries are the elasticities of investment with respect to the short term interest rate, calculated by simulating various investment equations in conjunction with the linkage equations whose implied elasticities are shown in Table 6. The investment equations for Germany, France, Italy and Spain are taken from Chatelain et al. (2003b) table 7.5. The most similar equations to these were used for the other four countries, with the Belgium estimates taken from Butzen et al. (2003; table 8.2, large manufacturing firms), the Austrian estimates taken from Valderrama (2001; table 3, benchmark model), the Finnish estimates were kindly provided by Topi and Vilmunen, and the Luxembourg estimates taken from Lünnemann P. and T. Mathä (2001; table 4, within estimates). The baseline data for the calculation of the elasticities is constructed from micro summary statistics, mean values.

* Since the model includes the cash stock, rather than the cash flow, the relative link equation is not the average of those of the four largest countries, but is imposed to be what is mechanically implied by the duration of the stock of cash, which is assumed to be equal to 4 months (1/3 of a year, implying a constant elasticity of -0.33$)$. \# The estimates underlying our calculations are Within (and not GMM as in all other cases). 


\section{Table 7: Summary of country papers testing for monetary policy induced loan supply shifts}

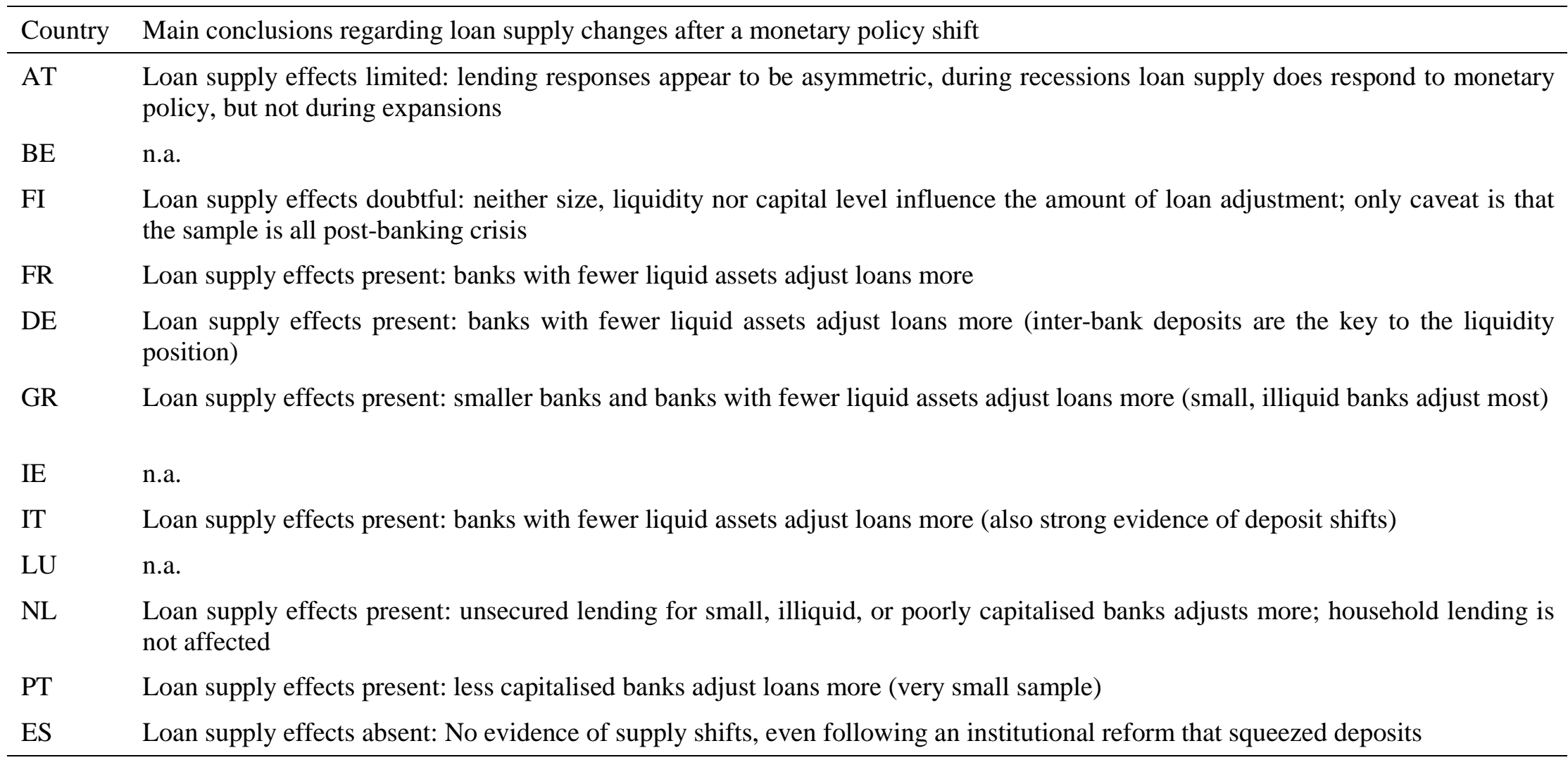


Table 8: Cumulative responses of bank variables to monetary policy shocks according to the Country level VARs

\begin{tabular}{|c|c|c|c|c|c|c|c|c|c|c|c|}
\hline & AT & BE & FI & FR & DE & GR & IE & IT & NL & PT & ES \\
\hline Initial VAR shock & 0.3 & 0.2 & 0.6 & 0.5 & 0.4 & 1.7 & 0.8 & 0.7 & 0.5 & n.a. & 0.9 \\
\hline Policy rate cum. 4 q. & 0.5 & 0.6 & 1.2 & 0.7 & 0.8 & 1.5 & 0.9 & 1.1 & 0.5 & 1.9 & \\
\hline \multicolumn{12}{|c|}{ Components of M3 and yield on time deposits (cumulated responses up to 4 quarters): } \\
\hline M1 & -1.1 & -1.3 & -1.2 & 0.1 & -0.7 & 0.2 & 0.0 & -1.8 & -2.4 & n.a. & -1.7 \\
\hline M3-M1 & 1.9 & 3.8 & 1.4 & 0.1 & 1.4 & -2.6 & 2.9 & -1.3 & 0.8 & n.a. & 1.1 \\
\hline Time deposit rates & n.a. & 0.2 & 0.2 & 0.7 & 0.7 & 0.0 & 0.7 & 0.8 & 0.1 & n.a. & 0.4 \\
\hline Summary & $\begin{array}{l}\text { Composition } \\
\text { affected }\end{array}$ & $\begin{array}{l}\text { Composition } \\
\text { affected }\end{array}$ & $\begin{array}{l}\text { Composition } \\
\text { affected }\end{array}$ & No effect & $\begin{array}{l}\text { Composition } \\
\text { affected }\end{array}$ & $\begin{array}{c}\text { Total } \\
\text { affected }\end{array}$ & $\begin{array}{l}\text { Wrong } \\
\text { effect }\end{array}$ & $\begin{array}{c}\text { Total } \\
\text { affected }\end{array}$ & $\begin{array}{l}\text { Composition } \\
\text { affected }\end{array}$ & n.a. & $\begin{array}{c}\text { Composition } \\
\text { affected }\end{array}$ \\
\hline \multicolumn{12}{|c|}{ Response of price and quantity of Loan rates (cumulated responses up to 4,8 and 12 quarters): } \\
\hline Short-term loan rates & n.a. & 0.4 & 0.6 & 0.7 & 0.7 & 0.0 & 0.7 & 0.8 & 0.7 & n.a. & 2.1 \\
\hline \multicolumn{12}{|c|}{ Loan volume responses (cumulated up to 4,8 and 12 quarters): } \\
\hline To firms (4 q.) & -0.6 & 1.1 & n.a. & -0.5 & 0.7 & -0.3 & n.a. & n.a. & n.a. & n.a. & 0.0 \\
\hline To firms (8 q.) & -0.3 & -1.5 & n.a. & -2.7 & 0.4 & -0.6 & n.a. & n.a. & n.a. & n.a. & -1.8 \\
\hline To firms (12 q.) & -1.7 & -5.0 & n.a. & -5.9 & -2.3 & -0.7 & n.a. & n.a. & n.a. & n.a. & -3.0 \\
\hline To households (4 q.) & -1.0 & -0.7 & n.a. & 0.1 & -1.4 & 0.1 & n.a. & n.a. & n.a. & n.a. & 0.4 \\
\hline To households (8 q.) & -0.1 & -1.4 & n.a. & 1.1 & -4.9 & 0.0 & n.a. & n.a. & n.a. & n.a. & -0.6 \\
\hline To households (12 q.) & 1.0 & -3.1 & n.a. & 3.9 & -9.0 & -0.1 & n.a. & n.a. & n.a. & n.a. & -1.3 \\
\hline Total (4 q.) & -0.1 & -0.4 & -2.1 & -0.1 & 0.2 & -0.2 & 0.3 & -1.8 & -0.2 & n.a. & 0.3 \\
\hline Total (8 q.) & -0.3 & -2.2 & -6.0 & -0.9 & -0.9 & -0.4 & 0.9 & -4.5 & -3.7 & n.a. & -0.4 \\
\hline Total (12 q.) & -1.2 & -4.8 & -11.0 & -2.3 & -3.8 & -0.5 & 1.3 & -7.2 & -7.2 & n.a. & -1.0 \\
\hline
\end{tabular}

Sources: Authors' calculation on the basis of the results of Mojon and Peersman (2001) 
Table 9: Final Assessment of Monetary Policy Transmission in Euro Area Countries

\begin{tabular}{|c|c|c|c|c|c|}
\hline \multirow[b]{2}{*}{ Bank evidence } & \multirow{2}{*}{$\begin{array}{l}\text { Data lacking to } \\
\text { determine relevance } \\
\text { of the IRC }\end{array}$} & \multicolumn{3}{|c|}{ IRC dominance rejected } & \multirow{2}{*}{\begin{tabular}{|l}
\multicolumn{1}{|c}{$\begin{array}{c}\text { IRC dominance no } \\
\text { rejected }\end{array}$} \\
$\begin{array}{l}\text { No financial factors } \\
\text { expected }\end{array}$
\end{tabular}} \\
\hline & & $\begin{array}{l}\text { Financial factors } \\
\text { expected for Investment } \\
\text { and potentially } \\
\text { important for } \\
\text { consumption }\end{array}$ & $\begin{array}{l}\text { Financial factors } \\
\text { potentially important for } \\
\text { consumption only }\end{array}$ & $\begin{array}{l}\text { Financial factors } \\
\text { expected for Investment } \\
\text { potentially important for } \\
\text { consumption }\end{array}$ & \\
\hline $\begin{array}{l}\text { Loan supply } \\
\text { reacts }\end{array}$ & NL, PT & GR, FR? & $\mathrm{DE}$ & IT, FR? & \\
\hline $\begin{array}{l}\text { Loan supply } \\
\text { insensitive }\end{array}$ & & & & AT & FI, ES \\
\hline $\begin{array}{l}\text { Loan supply } \\
\text { assessment not } \\
\text { possible }\end{array}$ & IR & BE? & & BE? & LU \\
\hline
\end{tabular}

Note: there is conflicting information about France and Belgium and therefore we show them as having two possibilities. 